\title{
DEVELOPING REGIONAL APPROACH FOR TRANSPORT INDUSTRY: THE ROLE OF PORT SYSTEM IN THE BALKANS
}

\author{
Bojan Beškovnik, Elen Twrdy \\ Faculty of Maritime Studies and Transportation, University of Ljubljana, Portorož, Slovenia \\ Submitted 12 June 2013; resubmitted 20 July 2013; accepted 20 August 2013; \\ first published online 14 July 2014
}

\begin{abstract}
The paper presents a wider perspective on possibilities to develop a regional strategy for efficient management of the transport industry in the region of the Balkans. The focus is mainly on ports, their actual and future role in transport industry and regional economy. A complete overview of the actual situation of port industry and inland infrastructure is presented. Based on a seven pillar model, other key elements, such as Information Technology (IT) systems in use, documentary procedures and managing strategies of ports in the Balkans were analysed. The main proposal is connected to the development of a regional role for ports on the eastern coast of the Adriatic Sea in order to secure port regionalization and specialization. On this basis, the inland infrastructure and other supporting elements as IT platforms and documentary procedures should be developed accordingly. The entire region and economy should benefit from such cooperation as new supply chains might be attracted.
\end{abstract}

Keywords: transport industry; ports; port infrastructure; port management; Adriatic Sea.

\section{Introduction}

The region of South East Europe is becoming a very interesting research matter from the transport and logistics industry perspective, due to the intention of investment by global manufacturing and logistics companies, and by arrival of global port operators in the region. Transport industry is therefore presenting the basis for the fast and intensive development of the entire region. Namely, in the era of a global crisis transport costs and transit time have become an important issue of product's total price reduction (Hummels 2007). The production centres are moving closer to the final consumer basins (Hummels 2007) and the Balkans region has been recognised as a possible alternative to the Middle East and Far East production. Such change and new production strategy was already implemented by various global producing enterprises, such as Fiat, Danieli, Grundfos, Johnson Controls, Bosch, Benetton, Ferrero, Geox, etc. and by global logistics companies as Kuehne \& Nagel, Schenker, DHL, etc.

This important initiative needs the support from the regional economy and transport industry in order to ensure lean and agile supply chains. Thus, the development of transport infrastructure and intermodal nodes, port modernisation and sustainable transport industry development become one of the crucial goals in the future development of the region. Managing of the entire transport network needs a new approach and vision where a regional development policy should be defined among all states in the Balkans. Such policy was managed after the Second World War. The issues of intermodality and the regional role of ports appear as important objects for an in-deep analysis of actual bottlenecks and possibilities, in order to define long-term regional strategy.

The importance of ports as intermodal nodes and the necessity of intermodality development to support the local industry is certainly not a new approach. It has been accentuated by different authors (Van Klink, Van den Berg 1998; Slack 1999; Juhel 2001; Notteboom, Winkelmans 2001; Notteboom, Rodrigue 2005). Robinson (2002) placed the role of a port as a completely new element in value driven supply chains. In addition, Dvorski (2005) analysed the interdependence between traffic and economy closely. Namely, with stronger local or regional economy, the port or intermodal systems have an important role in the region and vice versa because a modern and well-positioned system can gain faster and stronger development for the local and regional economy. 
Consequently, a need to define a regional approach towards the regional port and logistics strategy is foreseen. This research gives the basis for the technical and technological improvement of the transport infrastructure mostly related to the ports in the region of the Balkans in order to support the increasing intentions for foreign investments in production plants as well as innovative supply chain solutions. A proposal for developing port system in the Balkans is presented, where key elements of system's establishment are elaborated.

\section{Literature Basis and Cognitions about Port Regionalization and Port Systems}

The ports support the local or the regional economy, with their role in modern logistics. This has been exposed by Fujita et al. (999) and Clark et al. (2004), as they define ports as enablers of economies of scale for production and trade. In addition, mentioned authors see ports as providers of comparative advantages to regions and cities where they are located. Panayides (2006) and Pfaffmann (2007) expose that with the increasing value of import and export flow the role of maritime logistics and ports increases.

Robinson (2002) states that on this basis, some ports emerged as important generators in national economy, through added-value services, financial revenues and revenues generated by a vast number of transport and logistics companies involved in global supply chains. Passing the years, ports evolved into important international hub points, with an important and wider regional role. According to Notteboom (2010) this is more than evident in West European economy, where ports and an intermodal network have been intensively developed in the recent decades. $\mathrm{Li}$ (2007) exposes that based on these developments the new supply chain concepts were easily introduced by the industry, and such a policy influenced drastically the development of transport industry in Europe. Nowadays, intermodal nodes in Western and Northern parts of Europe handle more than $80 \%$ of all export or import cargo to or from Europe (Pfaffmann 2007). Rodrigue et al. (2010) see the reason in intensive investments and well equipped intermodal points with sophisticated machinery and well-educated and trained human resources; the same steps were adopted on hinterland infrastructure. Di Vaio et al. (2011) analysed the case of Italy, where the port infrastructure has been importantly developed as well, as ports play an important role not just in container or general cargo industry, but also in cruising industry.

Haarmeyer and Yorke (1993) expose that publicly owned ports cannot follow such development and build such a strong position in a short period, because of the underdeveloped intermodal infrastructure and scarcity of funds. To some extent, the managing philosophy is very often contributed to the slow development because States are the main shareholders in all ports where the private capital had only limited or no potentials for an adequate entrance. Haarmeyer and Yorke (1993) also state, that such system (government-owned and operated) faces many problems related to lack exposure and full commercial competitive pressures. Namely, publicly owned and operated ports may have reduced intention to operate efficiently and are often subject to political interference, causing poor and slow development. Authors expose that on the other hand, privately operated ports, are often more productive and interesting in new managing strategies.

As a result, different possible directions in development of ports as important regional players have been proposed in the recent years (Table 1). Notteboom and Rodrigue (2005) expose the necessity of port regionalisation and Medal-Bartual et al. (2012) the necessity for specialization in some cargo in sustaining local economy. Song (2003) proposes coordinate cooperation between ports from the same gravitational area, where they have to coordinate activities according to clients demand and potential sea transport services. De Langen (2012) goes further, as he proposes port's development as a cluster of economic activities and not just in a way of port services specialization. With such approach the port should still be focused on costs and agile performance. Thus Paixão and Marlow (2003) expose the necessity to develop fourth generation of ports, where agility on the entire intermodal route is one of the main focuses.

With a strategic cooperation between ports in a certain region a port system can be created. Thus 'port system' can be described as informal or formal cooperation among ports on some crucial issues related to goods orientation, developing port infrastructure, investments in hinterland infrastructure, etc. Such cooperation has been elaborated by Brooks et al. (2009), as authors propose strategic alliances among ports, with common marketing and commercial strategy. Besides, Stana et al. (2013) stresses the need of a uniformed IT platform implementation, in order to satisfy the needs for accurate data interchange, communication and integration between ports and other subjects from the business environment.

Moreover, according to Ducruet and Van Der Horst (2009) the focus of ports should be on strong logistics integration within a unique logistics network. Thus, a strong support from local governments and politics must be presented, in order to secure flexible legal frames, transport corridors, highway connections to the economic basins, hinterland intermodal nodes and important distribution centres. Of course, the private sector has an important role to enable faster modernisation with direct investments.

On the other hand, De Langen (2008) exposes that with potential cooperation as a unique 'system', ports must still be competitive in their port services and in hinterland connections. Namely, to some extent a monopoly market might be formed when strong and wellcoordinated regional port system is established. 
Table 1. Directions and strategies of port development and cooperation by author

\begin{tabular}{|c|c|}
\hline Author & Directions and strategies \\
\hline Haralambides (2002) & $\begin{array}{l}\text { Cooperation among ports but with strict supervision on prices, statistics and performed services, in order } \\
\text { to avoid negative impacts of cooperation. }\end{array}$ \\
\hline $\begin{array}{l}\text { Carbone, } \\
\text { De Martino (2003) }\end{array}$ & $\begin{array}{l}\text { Ports are described as important logistics clusters, where just integration into the supply chain is not } \\
\text { enough, but close cooperation between ports is requested to further enhance port's position in different } \\
\text { supply chains. To the some extent port specialization is foreseen. }\end{array}$ \\
\hline $\begin{array}{l}\text { Paixão, } \\
\text { Marlow (2003) }\end{array}$ & $\begin{array}{l}\text { Developing new concepts of port services with an aim on agility on the entire transport route, where } \\
\text { ports must secure optimal balance between services/costs/productivity. }\end{array}$ \\
\hline De Langen (2012) & $\begin{array}{l}\text { Developing ports as clusters of economic activities and not just in a way of port services specialization. } \\
\text { Important orientation on hinterland logistics services and simplified handling and documentary proce- } \\
\text { dures. }\end{array}$ \\
\hline $\begin{array}{l}\text { Notteboom, } \\
\text { Rodrigue (2005) }\end{array}$ & $\begin{array}{l}\text { Port regionalization, in order to serve specific supply chains in a wider region that is supported by new } \\
\text { investments and solutions for a specific supply chain. }\end{array}$ \\
\hline Li (2007) & $\begin{array}{l}\text { Transformation of ports services into more complex logistics services, where the port has a crucial role } \\
\text { in supply chain introduction on the market and in their transformation. }\end{array}$ \\
\hline Brooks et al. (2009) & $\begin{array}{l}\text { A formal and informal cooperation among ports from the same area is necessary to obtain multiple syn- } \\
\text { ergies, with common marketing and commercial strategy and by eliminating documentary procedures } \\
\text { for port-port transport chain. }\end{array}$ \\
\hline $\begin{array}{l}\text { Ducruet, } \\
\text { Van Der Horst (2009) }\end{array}$ & $\begin{array}{l}\text { Port transformation - from competitors to cooperation and evolution to competitors just in different } \\
\text { supply chains, where transport integration with developed hinterland connections is needed. }\end{array}$ \\
\hline $\begin{array}{l}\text { Rodrigue, } \\
\text { Notteboom (2009) }\end{array}$ & $\begin{array}{l}\text { P0rts must be oriented into complete process in the supply chain with a more active role of their port } \\
\text { terminals and hinterland terminals, and in developing port or terminal networks in shaping global lo- } \\
\text { gistics path solutions. }\end{array}$ \\
\hline Song (2003) & $\begin{array}{l}\text { Establishing port co-opetition; eliminating barriers in cooperation, with joint strategic decisions focused } \\
\text { on services and client's demand. }\end{array}$ \\
\hline Chang (2011) & $\begin{array}{l}\text { Each port has to develop a hub role in a specific supply chain, where ports must cooperate in develop- } \\
\text { ing seaborne trade links, and when possible, also developing coastal shipping links between ports in the } \\
\text { region. These activities should substantially increase economic activity of the region. }\end{array}$ \\
\hline Stana et al. (2013) & $\begin{array}{l}\text { Port integration within a single Electronic Data Interchange (EDI) platform to eliminate documentary } \\
\text { procedures, enhance data transfer and support supply chain, with transparent communication among } \\
\text { all subjects. }\end{array}$ \\
\hline
\end{tabular}

\section{The Model of Port System}

\subsection{Model Set-Up for Managing and Developing Ports}

Based on the introduced findings and strategies of developing port system; and on our previous analyses on ports in the Adriatic Sea (Beškovnik 2010, 2013; Beškovnik, Twrdy 2011) we see the necessity that the certain economic region formulates a common strategy for ports and for the entire transport industry. This is especially valid in regions with higher number of ports that compete among them for the same cargo and clients. With our researches we found out that regions with higher numbers of States and consequently borders should pay special care on legal and documentary procedures harmonization (with a single EDI platform), because these elements usually block the development of a wider port's gravitational area. Such situation inhibits intention of ports to support supply chains with integrated logistics concepts and potential investments in dry ports and inland infrastructure.

We propose a seven pillar model for a regional approach that should eliminate such circumstances and at the same time, secure a coordinated development of the entire transport industry and efficient port integration in the regional economy. The proposed seven pillar model consists of the following priorities (Fig. 1):

- inland infrastructure development;

- port infrastructure and suprastructure modernisation;

- uniformed IT platform on port and logistics level;

- simplifying legal and documentary procedures;

- new managing philosophies of ports;

- port regionalisation and specialization;

- financial support and private investments.

\subsection{A Seven Pillar Port System Strategy}

The role of a port in a supply chain and in regional economy changed drastically. Paixão and Marlow (2003) advocated that ports must introduce an agile logistic strategy to cope with new requests from the global market and support regional development efficiently. Namely, the competition among ports is increasing, thus these systems are forced to cut down waste operations, eliminate extra costs and secure reliable sea-side and landside services. This has been exposed and analysed by different researches (Vis, De Koster 2003; Steenken et al. 2004; Notteboom, Rodrigue 2005) where authors expose the importance of port and inland infrastructure in efficient support for different supply chains. 


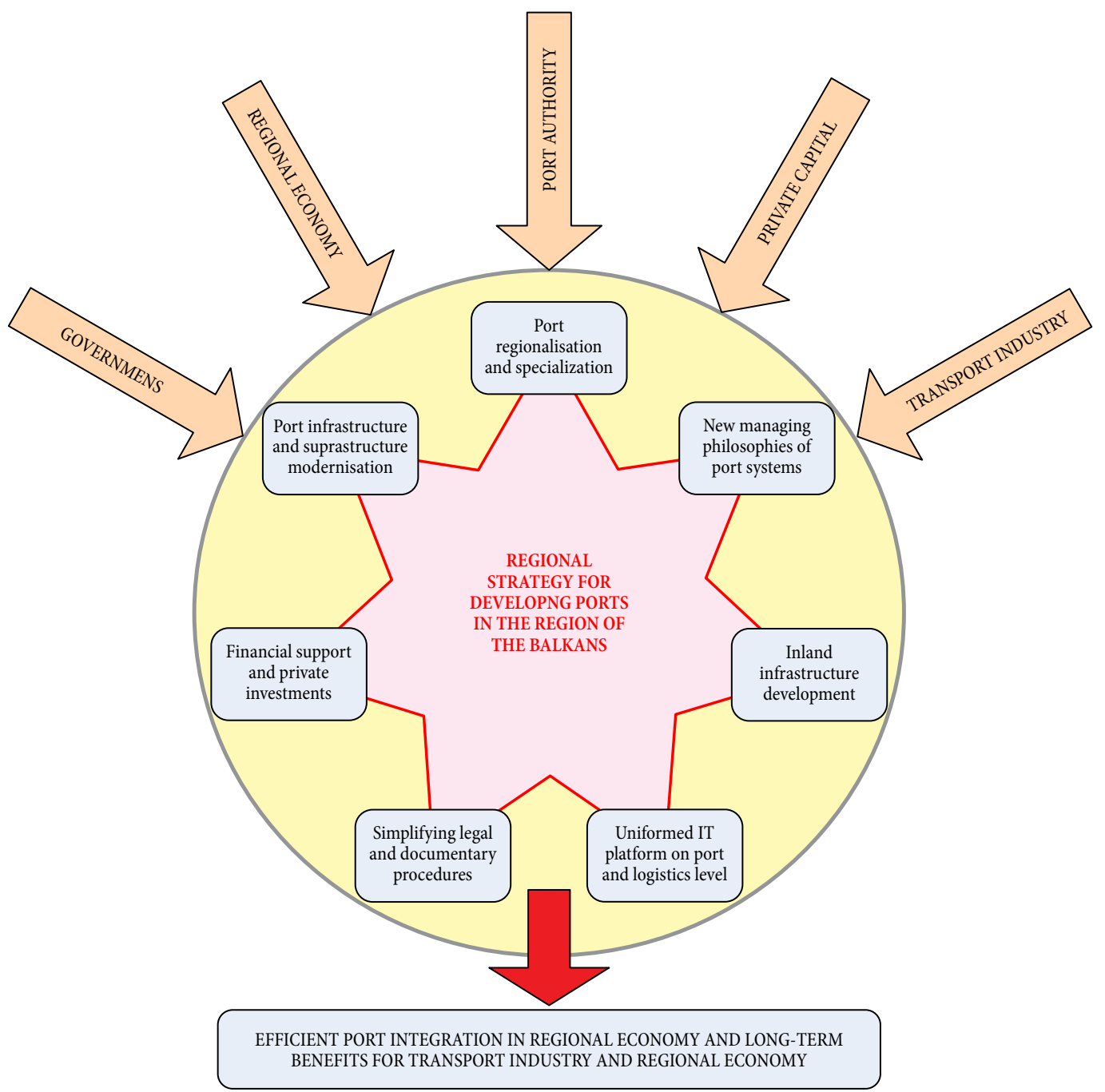

Fig. 1. Seven pillar regional model of ports' development within a single port system in the Balkans (source: model worked out by authors)

Undoubtedly, inland connections and inland infrastructure are the two basic transport elements supporting port's activities and development. To some extent they can be presented as a basic platform to develop ports and intermodality in a certain region. According to Dvorski (2005) it can be directly linked with the actual economical condition of the regional economy as stronger economies are intensively investing in transport infrastructure modernisation. Thus, these are two of the main pillars presented in the model of a regional port system development (Fig. 1).

Ports can secure lean operations with sophisticated technical equipment, higher handling capacities, modern infrastructure, optimal processes and trained manpower that are supported by new IT platforms. Establishing a cumulative IT data network, with uniformed information flow in quality and quantity is a must in modern logistics. EU and its Commission started with such vision several years ago. Still today they encourage researches of practical problems in implementing new EDI platforms related to intermodal logistic and with strong focus on ports.
Only in this way they can cope with an increasing volume of intermodal units to be handled in a short time and at a low cost. Of course, modernisation is connected to financial investments, which are limited nowadays, especially because the private capital cannot be invested in the infrastructure. In some cases it might be possible but present administrative and legal procedures hinder it.

On the other hand, the development and investments are always restricted to a certain circle, managed by the Port Authority, which is an extended arm of local or national state authority, or by a private operator. The most common and extreme managerial philosophies are the Continental (European) and Peninsular (AngloSaxon) philosophies. The difference between them is in the approach of acting on the market. The Anglo-Saxon approach manages the intermodal node as a commercial activity with an aim to obtain a profit, meanwhile on the opposite side is the European or Continental managing philosophy (McConville 1999), where the state has the power to decide about investments, modernization and system's organizational changes. The latter is predominantly present in southern ports where more aggressive 
commercial activity is missing. The transformation of managing philosophy is therefore an important element in adopting a new regional port policy.

One of the most important pillars is the strategy how a port specialization can be developed, without disturbing of refusing actual supply chains. We see the need of strong cooperation among semi-sized ports as these ports hardly compete with important international ports. The only way we see is the cooperation and specialization within a single regional port system.

\section{The Analyse of Key Elements on Eastern Adriatic Coast Ports and Hinterland Connections}

\subsection{Limited Role of Ports in South-East Europe}

Ports in South-East Europe are very often limited in their operational or commercial activities, due to superannuated port infrastructure, lack of investments by the State or by private investors, underdeveloped IT systems, administrative procedures, etc. Analysing and removing existing bottlenecks in ports are of crucial importance in infrastructure improvement and to secure higher added-value for the entire regional economy. Namely, the actual 'status quo' situation in South-East Europe does not contribute to the regional development. The lack of financial funds and the strong impact of global crisis further hinder important investments. This has been accentuated also by Tilling (2006) who sees the main bottleneck in the underdeveloped infrastructure and complete transport sector; and in practically nonexistent capacity of countries to even maintain the existing infrastructure and operational services. Based on the development of motorways of the sea in the South East Europe, Haralambous (2005) exposes six elements, out of which four are the main weaknesses connected to port and hinterland network infrastructure and to the local economy. They are:

- underdeveloped port-hinterland infrastructure (mainly by railway routes);

- superannuated railway infrastructure and connections in all ports;

- lack of common vision and strategy among states, regions and economies;

- absence of important multinational rail and logistic operators that could play the leading role for uniting interested participants.

Therefore, the actual pressure from the transport industry and new logistics concepts call for an analysis of the existing situation in the ports on the eastern coast of the Adriatic Sea and define a basis for a long-term coordinated strategy.

The following ports and their inland connections and integration are analysed: the Slovenian Port of Koper, two Croatian ports - Rijeka Port and the Port of Ploce, the Port of Bar in Montenegro and the Albanian Port of Durres (Fig. 2).

Hinterland intermodal terminals are not included in our survey, because there are no specialised intermodal terminals in the region presently. Some rail terminals are situated in the capital cities as Belgrade, $\mathrm{Za}$ greb, Ljubljana, Podgorica, Sarajevo, etc.

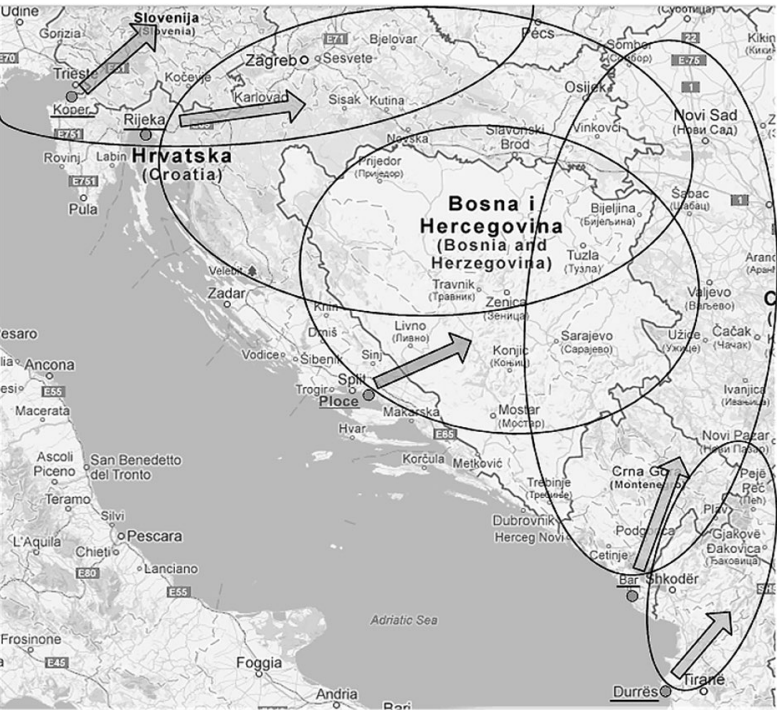

Fig. 2. Ports on the Eastern side of the Adriatic Sea and their hinterland markets (source: prepared by authors)

\subsection{Inland Connections and Infrastructure}

The thesis that the South-European transport infrastructure is underdeveloped can be confirmed by the comparison between Western European rail and road infrastructure and the South Eastern one.

The difference is mainly in the railway infrastructure. The fact that States in the Balkans intensively invested just in highways development and modernisation, made a huge disproportion between these two modes. Namely, the highway connections with the regional ports were under important construction in recent years and some connections are in a final stage. Just the opposite is the situation with the rail infrastructure. Ports and hinterland terminals are not adequately connected, as this was done immediately after the Second World War, thus the capacity of rail lines from the ports is overwhelming. The reason is in just one rail track, superannuated infrastructure and lack of new specialised wagons.

In addition, the use of rail transport in the Balkans decreased drastically from 1990, when new States appeared. To some extent, this is the main reason why the railway infrastructure was not supported by public or private investments. This is evident in the data collected in Table 2 as the total length of railway lines in South East Europe was reduced by over $300 \mathrm{~km}$ in the analysed countries from 2001 to 2010. Nowadays, it stands at a little bit more than $28190 \mathrm{~km}$, where $10700 \mathrm{~km}$ of railway lines are operated in the Balkans. On the other hand, during the same period some Western European countries increased the railway network, especially in Spain, Germany and Belgium (Table 2).

The thesis of underdeveloped rail network can be confirmed also through the data of rail line density in $\mathrm{km}$ per $100 \mathrm{~km}^{2}$. Developed Western and Northern European countries have three to even seven times higher rail line density compared to the Balkan States. If there is no modernisation action shortly, the discrepancy will become even greater within this decade. 
Table 2. Total length of railway lines and rail network density between 2001 and 2010 (Eurostat 2013)

\begin{tabular}{|c|c|c|c|c|c|}
\hline \multirow{2}{*}{ Country } & \multicolumn{2}{|c|}{ Total length $[\mathrm{km}]$} & \multicolumn{2}{|c|}{ Railway line density $\left[\mathrm{km} / 100 \mathrm{~km}^{2}\right]$} & \multirow{2}{*}{$\begin{array}{c}\text { Change of length } \\
2010 / 2001\end{array}$} \\
\hline & 2001 & 2010 & 2001 & 2010 & \\
\hline Belgium & 3454 & 3578 & 11.31 & 11.72 & 103.6 \\
\hline Czech Republic & 9523 & 9568 & 12.07 & 12.13 & 100.4 \\
\hline Germany & 35986 & 37679 & 10.08 & 10.55 & 104.7 \\
\hline Spain & 12310 & 13853 & 2.44 & 2.75 & 112.5 \\
\hline Netherlands & 2809 & 2888 & 6.76 & 6.95 & 102.8 \\
\hline Slovenia & 1228 & $1209^{*}$ & 6.06 & 6.15 & 98.5 \\
\hline Croatia & 2726 & $2722^{*}$ & 4.82 & 4.81 & 99.8 \\
\hline Macedonia & 699 & $699^{*}$ & 2.72 & 2.72 & 100 \\
\hline Albania & - & 447 & - & 1.56 & - \\
\hline Montenegro & 250 & 250 & - & 1.79 & 100 \\
\hline Bosnia and Herzegovina & - & $1031^{*}$ & - & 2.02 & - \\
\hline Serbia & - & $4347^{\star}$ & - & 4.92 & - \\
\hline Bulgaria & 4320 & 4144 & 3.89 & 3,73 & 95.8 \\
\hline Romania & 11015 & 10785 & 4.64 & 4.54 & 97.9 \\
\hline Greece & 2377 & 2558 & 1.8 & 1.93 & 107.6 \\
\hline
\end{tabular}

Note: ${ }^{\star}$ - valid in 2012.

Based on the elaborated analysis it can be affirmed that the railway network on the Eastern side of the Adriatic Sea is not developed enough to secure optimal logistics and proper port development. According to Limbourg and Jourquin (2009), railway transport should be used as the key transport solution between ports and hinterland hub nodes, distribution points or producing plants, and combined road-rail transport should be preferably used only on shorter transport routes up to max. $300 \mathrm{~km}$; mostly when direct to door deliveries are requested.

As the railway infrastructure being in use cannot secure lean logistics in the Balkans the rail transport needs huge support by road transport to ensure modern logistics concepts. Namely, according to our research the rail network represents just $6.1 \%$ of total inland transport network in the Balkans. Besides this, the transport speed in some sections is even below $20 \mathrm{~km} / \mathrm{h}$. An average transport speed is around $40 \mathrm{~km} / \mathrm{h}$.

On the contrary, road infrastructure is much more developed. As shown in Table 3, the total length of road network in the Balkans stands at about $165600 \mathrm{~km}$. No more than $2880 \mathrm{~km}$ or $1.74 \%$ of all road networks is highway, where just Macedonia and Croatia are above this low average. On the other hand, Western Balkans has higher highway density, where only Slovenia has a well-developed road network of over $191 \mathrm{~km} / 100 \mathrm{~km}^{2}$ of the state area. Based on the presented data it can be ascertained that in average such an infrastructure does not allow high transport speed and cannot secure high security standards.

From the performed analysis it can be understood that the hinterland infrastructure does not provide an adequate support to port development. Moreover, Gojkovic Bukvic (2012) exposes that it is hindering the development of green logistics concepts through ports in the Balkans, where ports might benefit from these concepts. The main limiting factor is the fact that the inland transport infrastructure is in worse conditions close to the ports, as some of them are still not connected with the highways and rail tracks connecting the port with rail network have limited capacity.

Table 3. Total length of roads and road density in the Balkans (valid in the year 2012, data collected from national road transport statistics)

\begin{tabular}{lccccc}
\hline \multicolumn{1}{c}{ Country } & Roads $[\mathrm{km}]$ & Highways $[\mathrm{km}]$ & Highways/Roads [\%] & Road density $\left[\mathrm{km} / 100 \mathrm{~km}^{2}\right]$ & Rail/road [\%] \\
\hline Albania & 18000 & 170 & 0.94 & 62.72 & 44.82 \\
\hline $\begin{array}{l}\text { Bosnia and } \\
\text { Herzegovina }\end{array}$ & 22900 & 0 & 0.00 & & 4.50 \\
\hline Croatia & 28400 & 1340 & 4.72 & 50.27 & 9.58 \\
\hline Macedonia & 9570 & 190 & 1.99 & 37.24 & 7.30 \\
\hline Montenegro & 5174 & 0 & 0.00 & 36.96 & 4.83 \\
\hline Serbia & 42690 & 560 & 1.31 & 48.31 & 10.18 \\
\hline Slovenia & 38873 & 620 & 1.59 & 191.78 & 3.16 \\
\hline
\end{tabular}




\subsection{Port Infrastructure and Technical Equipment}

According to the analysed data, the port's infrastructure and superstructure in use are very poor. All analysed ports, except, to some extent Koper port, are infrastructural underdeveloped on the sea side, where the suprastructure (as berth cranes) is superannuated as well. Almost the same conditions are on the land side. To some extent this is evident by basic infrastructure data for container and RO-RO terminals collected in Table 4.

Our analysis of port infrastructure exposes that all the observed systems operate only 10 specialised RORO ramps, where Koper port and Durres port operate $80 \%$ out of this or 4 ramps each. On the other hand, the Rijeka port does not have specialised RO-RO ramps and therefore cannot provide RO-RO port service. Consequently, the development of RO-RO transport within motorways of the sea services is not possible, which should significantly contribute to regions' economic development. In addition, in all other ports the quay for container or RO-RO vessel is the same, which leads to severe congestion when both maritime services (container handling and RO-RO units handling) are served.

Besides infrastructure, the technical equipment is superannuated. The most important limiting factor for ports in Montenegro and Albania is that neither of them operates specialised container berth cranes. Furthermore, the situation on the yard area is not satisfactory for the increased industry demand. Container handlings are performed by reach-stakers or forklifts as container gantry cranes are not in use. The achieved performance is lower and produces wastes and higher handling costs.

The situation of the infrastructure and suprastructure for general cargo and bulk cargo is better, as technology and technical equipment do not have so much influence on port competitiveness. Of course, superannuated infrastructure and suprastructure gain higher operational and handling costs due to low productivity, but this is not as evident as it is in the container handling. Even in this field, the Port of Koper is the leading port from the technical and technological point of view. Technical equipment in use, enabling the port to reach the presented handling capacities, consists of a computer-controlled closed conveyor system for unloading of ships, a ship loader with an anti-dust telescopic tube and loading/unloading machines on the terminal area. Technology using the system of sprinkling towers and an aluminium barrier $(11 \mathrm{~m})$ around the terminal has been installed (Luka Koper 2012).

Regarding capacities for bulk cargo the Port of Ploce is close to the Port of Koper. Namely, the former has $510 \mathrm{~m}$ of quay length with three berths. The yard capacity is approximately 300000 tons and the daily handling capacity is 15000 tons. The main difference is that the port does not use a conveyor system, but just five berth cranes.

Other ports also handle bulk and general cargo but their technical equipment cannot be compared to the one used by western and northern European ports. Thus, ports cannot be cost effective, and secondly, they cannot maintain requested service schedules and the so
Table 4. Basic port infrastructure data for container and RO-RO terminals (data collected from port's statistics)

\begin{tabular}{lcccc}
\hline Port & $\begin{array}{c}\text { Quay } \\
\text { length }[\mathrm{m}]\end{array}$ & $\begin{array}{c}\text { Draught } \\
{[\mathrm{m}]}\end{array}$ & $\begin{array}{c}\text { RO-RO } \\
\text { ramps }\end{array}$ & $\begin{array}{c}\text { Yard capacity } \\
{\left[\mathrm{m}^{2}\right]}\end{array}$ \\
\hline Bar & 770 & 12 & 1 & 65000 \\
\hline Durres & 700 & 10 & 4 & 30000 \\
\hline Koper & 1400 & 11.4 & 4 & 1135000 \\
\hline Ploce & 300 & 13.8 & 1 & 38000 \\
\hline Rijeka & 460 & 11 & 0 & 135500 \\
\hline
\end{tabular}

important transit times. They cannot secure an agile service in a supply chain. Moreover, they compete among each other for almost the same market in the Balkans (Fig. 2). Namely, the Koper port aims at serving central European countries but at the same time it is competing for Croatian and Serbian cargo flows. Almost the same situation is valid for Rijeka port. Other three ports look mainly for south European market, where they have to compete with the northern Adriatic ports of Koper and Rijeka. Greek ports as the Port of Piraeus and Thessaloniki port are very strong competitors as well. This is especially valid for cargo flows to Macedonia, Serbia and Albania.

\subsection{IT Systems and Documentation Procedures}

Some European ports have made important steps in developing EDI systems with all important port subjects. Unfortunately, this is not the practice in the Balkans. Ports, hinterland terminals, shipping lines, shipping agents, rail operators, logistics companies and local authorities are not connected through uniformed IT system. There is a strong need to develop a uniformed IT platform, which would connect all logistics providers on an integrated IT chain.

Namely, only the Port of Koper has developed an EDI system that to some extent unifies data exchange between clients, authorities and operators. Other ports do not use unified IT platforms in direct communications. For instance, Durres port still requests hard copy documents, which can be handed over manually or as scanned documents by e-mail system. The same practice is in force with other layers such as the police and the customs authorities, phytosanitary inspections, etc. where multi-copies of documents are requested. This situation is changing gradually, but the main problem is that each port and each logistics operator is developing its IT platform and a simplified connection between all parties will not be possible.

The solution of this complicated situation might be included in a regional approach to develop a standardised IT tools and/or IT platform, as proposed in our model. Different ports might use almost the same IT programme. This would simplify data exchange between shipping lines, rail operators and logistics companies. As they are present almost in all ports they could work on a unique platform. Consequently, this would fasten the entire supply chain and the transport sector would help the economy significantly. Anyhow, the main issue 
remains on how to motivate all transport and logistics entities to accede to this important project. Certainly, a top down model is needed, where governments and transport ministries should achieve wider agreements for the region.

\subsection{Managing Strategies in Use}

According to the performed observation the port management had no strong commercial vision after the Second World War. Ports and specialized terminals were developed by the ex-Yugoslav government's decisions and primarily to cover the needs of the joint national economy. The case of Albanian port Durres is more specific, but the country was highly isolated and the port was the only way of making bilateral trade with Italy.

Consequently, direct competition between these ports was not present. To some extent, ports served also other hinterland countries such as Hungary and Slovakia, while Austria was more oriented to Trieste port. Ports under study had between two to three specialized terminals which operated to serve just a few main clients. No special sales effort was needed.

The ports were not managed as intermodal nodes and important supply chain links for decades, since the managing philosophy was focused exclusively on handling of goods, without a general logistics view. During the last two decades and after the war in the Balkans, the ports changed their strategy. Today they are more opened for commercial activities and cooperation with the different logistics operators. Anyhow, the barrier remains in the infrastructure and suprastructure, where fast improvements are not possible. This is also valid for rail, road and intermodal operators and huge investments would be needed to improve the actual situation. According to some researches performed by State Ministries 500 million EUR should be immediately invested in maritime and river ports for the needed modernisation. Additionally, 1 billion EUR should be secured for the inland waterway modernisation and about 4 billion EUR for the railway modernisation and new intermodal terminals in the Balkans.

As the region is not in a condition to provide this amount of funds shortly, it is evident that a long- term strategy for the Balkans region has to be adopted. Nowadays, various states are present in the region with their national priorities therefore a consensus among them will be needed. The port regionalization strategy might be the right step. On this basis, the hinterland infrastructure and supporting activities should also be developed in the future.

Consequently a common managing strategy should be developed for port system in the Balkans. With such an approach another pillar from our model would be covered.

\subsection{Missing Port Specialization}

Acknowledgments regarding poor port infrastructure and suprastructure and analysed actual port throughput call for the actions of modernisation. This has to be done in coordination with activities of port regionalisation and specialization. Ports must define their primarily market and focus their development activities to satisfy the selected market.

Port regionalization and specialization on a regional level might be agreed by a common strategy accepted between different national governments and ministries. We see that the Port of Koper should be oriented on the central European and local market, where containerisation, automotive logistics including RO-RO and bulk cargo should be mainly developed. The port of Rijeka should also support containerisation, but aim at Hungary, Serbia, Bosnia and Herzegovina and local market. In addition, we propose specialization in liquid terminal development to become main regional port on western Balkans for liquids (Fig. 3).

The Port of Ploce should cover the principal demand for bulk cargo transport generated by the regional economy. Containerisation should not be the first-step development priority, as northern Adriatic ports can cover actual demand from the central European market and from the Balkans. This should be valid also for the Port of Bar. Port's specialization might be focused on supporting automotive industry development in Serbia, Bulgaria and vehicle production in Romania. Namely, FIAT's plant will produce over 250000 vehicles per year
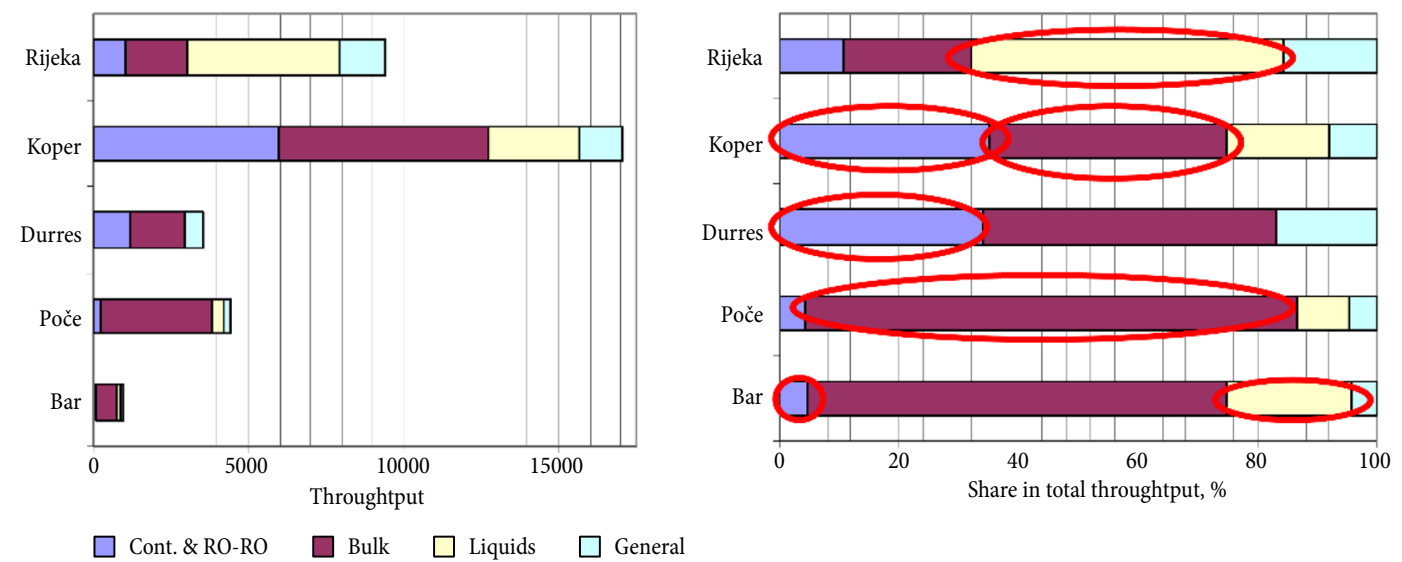

* Liquids at Durres port are handled by neighbour terminal Romano Port - approximately 600 t/year

Fig. 3. Port throughput and the main future orientation - throughput in 1000 tons (source: prepared by authors) 
from 2014 onwards. Significant quantity will be shipped from Kragujevac to Mediternaean ports or destinations in the Middle East. Almost the same development is foreseen for Dacia's plant in Romania. Port of Bar might cover this regional request through automotive specialization. On the other hand specialization on liquids might open the opportunity to become hub point for eastern Balkans. Port of Durres should play a significant role on the VIII. Pan-European transport corridor connecting Italy with Black sea markets of Bulgaria, Romania and Ukraine. Therefore a specialization in RO-RO and container handling should be set-up as a port's regional priority. Of course, bulk cargo should be developed as well due to important national export flows.

With described set-up a regional role for each port should be assigned within proposed port system in the Balkans. Of course, such strategy is not easy to be modelled as it depends significantly on governmental readiness for such a regional approach. Anyhow, with the described delimitation other supporting activities should be developed accordingly. Namely, investments in inland infrastructure should be based on port specialization (example - the Port of Bar should be efficiently connected with Kragujevac by modern rail infrastructure).

\section{Practices in Use and Foreseen Difficulties in Model Application}

The presented analysis predicts big difficulties in model adoption. According to Monios and Wilmsmeier (2012) this is the practice also in other port systems in Europe and across the USA. Ports rather compete among them that find a common strategy of development even they all expose the need of cooperation on the global market. But in reality they fight for each single voyage call and new business. In addition, Wilmsmeier andMonios (2013) consistently analysed the situation in the UK. Authors note a lack of cooperation among ports that goes in favour of big international ports, causing underdevelopment of smaller ports in Scotland and in some areas around the UK. The authors raise the question about port policy and the need of coordination.

Ducruet and Van Der Horst (2009) see better cooperation among ports and other subject on the northern Europe than in southern ports. Northern ports have better connections and well developed IT platforms compared to the southern ones. This call for immediate actions in south Europe, even some obstacles are more than evident.

Consequently, two methods of agreement achievements are possible. The first one is the so-called topdown method and the second one is a bottom-up method. The first method is exposed also by Rodrigue et al. (2001) as they say that with a top-down method faster implementation of actions is possible. Of course, these actions should be defined and executed by the governments or Port authorities. Multi-lateral agreements about port regionalization and specialization and inland infrastructure modernization on the entire route, crossing several states, should be determined.
On the contrary, Parantainen and Meriläinen (2007) prefer a bottom-up approach when concrete projects or agreements have to be realised. The main advantage of the method is that the industry is in position to present its expectations and needs to governments. Besides, it can directly co-create a strategy on a macro level and importantly influence governmental investments in transport infrastructure and the future port development.

For sure, a strong need for a suitable model is present therefore a mix of both methods should speed-up the entire process. Such studies and initiatives should help to establish an innovative environment on a regional level. Thus, scientific acknowledgments and proposals might stimulate governments to take the first steps toward a formulation of specialized groups of governmental institution, where private sector might be invited accordingly. In this way, the foreseen difficulties might be restrained in a shorter period.

In order to speed-up the entire process, all involved parties might immediately start with simplified legal, documentary and IT procedures as described in presented model. Of course, this has to be supported by new managing philosophy by both port authorities and port management. Their role in the regional context should be clear and harmonised with strategies of other ports. In this way it would be easier to attract private investments or secure national funds for port development. Clear vision and long-term strategy are strong assurances that the return on investments will be higher compared to the present situation. The entire region should benefit from proposed port system development.

\section{Conclusions}

The role of ports in a supply chain and in a regional economy changed drastically during the last twenty years. This is valid for South-East Europe and the region of the Balkans. Even the existing ports on the eastern coast of the Adriatic Sea hardly support the increasing demand from the industry with modern technologies in use and with modern logistics concepts. To some extent, the inland infrastructure is hindering their role.

With the proposed seven pillar model an appropriate regional set-up for each port should be assigned and a proper port system should be formed by all involved States in the Balkans by placing different levels of integration and cooperation. Moreover, the port specialization on just two to three terminals is going to reduce regional competitiveness and secure recognisable role of each port. On this basis port and hinterland infrastructure should be modernised and further developed. With the proposed delimitation other supporting elements should be developed as well. The main focus should be on a uniformed IT platform for standardised EDI in the supply chain and simplifying documentary and legal processes.

Unfortunately, the regional industry does not have a clear idea about a port's role or which port to use as the best logistics solution. Besides, fast improvements 
in infrastructure and suprastructure modernisation are not possible, as the region is financially limited and the global financial crisis even strengthens this pressure. Consequently, a long-term regional strategy is needed, where different elements should be developed and coordinated between different governments and port authorities in the region.

Consequently, a need for changing managerial philosophy in the ports is more than evident. Only in this way faster private financial funds might be secured and more transparent and long-term financial investments by the States might be achieved.

By further research of ports, infrastructure in use and developing supply chains in the Balkans, different strategies can be formulated, enabling further exploration and more nuanced understanding of the institutional aspects of port's spatial development.

\section{References}

Beškovnik, B. 2013. Possibilities for motorways of the sea development in the eastern part of the Adriatic Sea, Polish Maritime Research 20(1): 87-93.

http://dx.doi.org/10.2478/pomr-2013-0010

Beškovnik, B. 2010. Managing and organizational changes of intermodal network in transition regions: the case of South-East Europe, Transport Problems - Problemy Transportu 5(2): 37-47.

Beškovnik, B.; Twrdy, E. 2011. Agile port and intermodal transport operations model to secure lean supply chains concept, Promet - Traffic\&Transportation 23(2): 105-112. http://dx.doi.org/10.7307/ptt.v23i2.137

Brooks, M. R.; Mccalla, R.; Pallis, A. A.; Van Der Lugt, L. M. 2009. Coordination and Cooperation in Strategic Port Management. Working Paper. Dalhousie University, Canada. $23 \mathrm{p}$.

Carbone, V.; De Martino, M. 2003. The changing role of ports in supply-chain management: an empirical analysis, Maritime Policy \& Management 3(4): 305-320.

http://dx.doi.org/10.1080/0308883032000145618

Chang, Y.-C. 2011. Maritime clusters: what can be learnt from the South West of England, Ocean \& Coastal Management 54(6): 488-494.

http://dx.doi.org/10.1016/j.ocecoaman.2011.03.005

Clark, X.; Dollar, D.; Micco, A. 2004. Port efficiency, maritime transport costs, and bilateral trade, Journal of Development Economics 75(2): 417-450.

http://dx.doi.org/10.1016/j.jdeveco.2004.06.005

De Langen, P. W. 2012. Analysing the performance of seaport clusters, in D. Pinder, B. Slack (Eds.). Shipping and Ports in the Twenty-first Century. Routledge, 82-98.

De Langen, P. W. 2008. Ensuring Hinterland Access: the Role of Port Authorities, Discussion Paper No 2008-11. OECD/ International Transport Forum. 18 p. Available from Internet: http://www.internationaltransportforum.org/jtrc/ discussionpapers/DP200811.pdf

Di Vaio, A.; Medda, F. R.; Trujillo, L. 2011. An analysis of the efficiency of Italian cruise terminals, International Journal of Transport Economics - Rivista Internazionale de Economia dei Trasporti 38(1): 29-46.

Ducruet, C.; Van Der Horst, M. 2009. Transport integration at European ports: measuring the role and position of intermediaries, European Journal of Transport and Infrastructure Research 9(2): 121-142.
Dvorski, S. 2005. Međuovisnost prometa i gospodarstva, Suvremeni promet 25(1/2): 121-125 (in Croatian).

Eurostat. 2013. Available from Internet: http://epp.eurostat. ec.europa.eu/portal/page/portal/transport/data/main_tables

Fujita, M.; Krugman, P.; Venables, A. J. 1999. The Spatial Economy: Cities, Regions, and International Trade. The MIT Press. 384 p.

Gojkovic Bukvic, N. 2012. Contribution of new intermodal logistics chain: idea for the EU Future and better environment - Balkan challenge, International Journal of Engineering and Technology 4(2): 203-207.

http://dx.doi.org/10.7763/IJET.2012.V4.349

Haarmeyer, D.; Yorke, P. 1993. Port Privatization: an International Perspective. Policy Study No. 156. The Reason Foundation, Los Angeles, CA. 24 p. Available from Internet: http://reason.org/files/6a983123788632131171e022e6466a 7a.pdf

Haralambides, H. E. 2002. Competition, excess capacity, and the pricing of port infrastructure, International Journal of Maritime Economics 4(4): 323-347.

http://dx.doi.org/10.1057/palgrave.ijme.9100053

Haralambous, G. 2005. The contribution of the "Sea Motorways" to the European transport policy, in Young Researchers Seminar 2005. European Conference of Transport Research Institutes (ECTRI), 11-13 May 2005, Hague, Netherlands. 16 p. Available from Internet: http://www.ectri.org/ YRS05/Papiers/Session-2ter/haralampous.pdf

Hummels, D. 2007. Transportation costs and international trade in the second era of globalization, Journal of Economic Perspectives 21(3): 131-154. http://dx.doi.org/10.1257/jep.21.3.131

Juhel, M. H. 2001. Globalisation, privatisation and restructuring of ports, International Journal of Maritime Economics 3(2): 139-174. http://dx.doi.org/10.1057/palgrave.ijme.9100012

Li, L. 2007. Supply Chain Management: Concepts, Techniques and Practices: Enhancing the Value through Collaboration. World Scientific Publishing Company. 372 p.

Limbourg, S.; Jourquin, B. 2009. Optimal rail-road container terminal locations on the European network, Transportation Research Part E: Logistics and Transportation Review 45(4): 551-563. http://dx.doi.org/10.1016/j.tre.2008.12.003

Luka Koper. 2012. Luka Koper Company. Available from Internet: http://www.luka-kp.si

McConville, J. 1999. Economics of Maritime Transport: Theory and Practice. Witherby \& Company Ltd. 394 p.

Medal-Bartual, A.; Molinos-Senante, M.; Sala-Garrido, R. 2012. Benchmarking in Spanish seaports: a tool for specialization, International Journal of Transport Economics Rivista Internazionale de Economia dei Trasporti 39(3): 329-348.

Monios, J.; Wilmsmeier, G. 2012. Giving a direction to port regionalisation, Transportation Research Part A: Policy and Practice 46(10): 1551-1561. http://dx.doi.org/10.1016/j.tra.2012.07.008

Notteboom, T. E. 2010. Concentration and the formation of multi-port gateway regions in the European container port system: an update, Journal of Transport Geography 18(4): 567-583. http://dx.doi.org/10.1016/j.jtrangeo.2010.03.003

Notteboom, T. E.; Rodrigue, J.-P. 2005. Port regionalization: towards a new phase in port development, Maritime Policy \& Management 32(3): 297-313. http://dx.doi.org/10.1080/03088830500139885 
Notteboom, T. E.; Winkelmans, W. 2001. Reassessing public sector involvement in European seaports, International Journal of Maritime Economics 3(2): 242-259. http://dx.doi.org/10.1057/palgrave.ijme.9100008

Paixão, A. C.; Marlow, P. B. 2003. Fourth generation ports - a question of agility?, International Journal of Physical Distribution \& Logistics Management 33(4): 355-376. http://dx.doi.org/10.1108/09600030310478810

Panayides, P. M. 2006. Maritime logistics and global supply chains: towards a research agenda, Maritime Economics \& Logistics 8(1): 3-18. http://dx.doi.org/10.1057/palgrave.mel.9100147

Parantainen, J.; Meriläinen, A. 2007. The Baltic Sea motorway - recent development and outlook for the future, Journal of Maritime Research 4(2): 21-30.

Pfaffmann, E. 2007. Growth of Maritime Intermodal Cargo Challenges and Opportunities for Rail. Presentation. 7 p. Available from Internet: http://www.uic.org/diomis/IMG/ pdf/13-raillion.pdf

Robinson, R. 2002. Ports as elements in value-driven chain systems: the new paradigm, Maritime Policy \& Management 29(3): 241-255.

http://dx.doi.org/10.1080/03088830210132623

Rodrigue, J.-P.; Debrie, J.; Fremont, A.; Gouvernal, E. 2010. Functions and actors of inland ports: European and North American dynamics, Journal of Transport Geography 18(4): 519-529. http://dx.doi.org/10.1016/j.jtrangeo.2010.03.008

Rodrigue, J.-P.; Notteboom, T. 2009. The terminalization of supply chains: reassessing the role of terminals in port/ hinterland logistical relationships, Maritime Policy \& Management 36(2): 165-183. http://dx.doi.org/10.1080/03088830902861086

Rodrigue, J.-P.; Slack B.; Comtois, C. 2001. Green logistics (the paradoxes of), in A. M. Brewer, K. J. Button, D. A. Hensher (Eds.). Handbook of Logistics and Supply-Chain Management. Pergamon.

Slack, B. 1999. Satellite terminals: a local solution to hub congestion?, Journal of Transport Geography 7(4): 241-246. http://dx.doi.org/10.1016/S0966-6923(99)00016-2

Song, D.-W. 2003. Port co-opetition in concept and practice, Maritime Policy \& Management 30(1): 29-44. http://dx.doi.org/10.1080/0308883032000051612

Stana, A.; Meka, E.; Sevrani, K.; Baholli, I. 2013. From traditional business toward social business: a single window e-platform for the Albanian port community system, Academic Journal of Interdisciplinary Studies 2(2): 191-199. http://dx.doi.org/10.5901/ajis.2013.v2n2p191

Steenken, D.; Voß, S.; Stahlbock, R. 2004. Container terminal operation and operations research - a classification and literature review, OR Spectrum 26(1): 3-49. http://dx.doi.org/10.1007/s00291-003-0157-z

Tilling, C. 2006. The EU common transport policy for southeast Europe - what makes it a factor of cohesion and sustainability?, SEER - South-East Europe Review for Labour and Social Affairs 1: 7-14.

Van Klink, H. A.; Van den Berg, G. C. 1998. Gateways and intermodalism, Journal of Transport Geography 6(1): 1-9. http://dx.doi.org/10.1016/S0966-6923(97)00035-5

Vis, I. F. A.; De Koster, R. 2003. Transshipment of containers at a container terminal: an overview, European Journal of Operational Research 147(1): 1-16. http://dx.doi.org/10.1016/S0377-2217(02)00293-X

Wilmsmeier, G.; Monios, J. 2013. Counterbalancing peripherality and concentration: an analysis of the UK container port system, Maritime Policy \& Management 40(2): 116132. http://dx.doi.org/10.1080/03088839.2012.756588 